\title{
Biodiesel production from vegetable oil: Process design, evaluation and optimization
}

\author{
Hamid Reza Kianimanesh ${ }^{1}$, Farzin Abbaspour-Aghdam ${ }^{1 *}$, Mehrab Valizadeh Derakhshan ${ }^{2}$ \\ ${ }^{1}$ Sahand University of Technology, Biotechnology Research Center, Faculty of Chemical Engineering, Tabriz, Iran \\ ${ }^{2}$ Amirkabir University of Technology (TehranPolytechnic), Departmentof Chemical Engineering, Tehran, Iran \\ "Corresponding author: e-mail: f_abbaspour@sut.ac.ir
}

\begin{abstract}
To investigate the effect of reactor performance/configuration of biodiesel production on process parameters (mass $\&$ energy consumption, required facilities etc.), two diverse production processes (from vegetable oil) were implemented/designed using Aspen HYSYS V7.2. Two series reactors were taken into account where overall conversion was set to be $97.7 \%$ and $70 \%$ in first and second processes respectively. Comparative analysis showed that an increase in conversion yield caused to consumption reduction of oil, methanol, cold energy and hot energy up to $9.1 \%, 22 \%, 67.16 \%$ and $60.28 \%$ respectively; further, a number of facilities (e.g. boiler, heat exchanger, distillation tower) were reduced. To reduce mass \& energy consumption, mass/heat integration method was employed. Applying integration method showed that in the first design, methanol, cold and hot energy were decreased by $49.81 \%$, $17.46 \%$ and $36.17 \%$ respectively; while in the second design, oil, methanol, cold and hot energy were decreased by $9 \%, 60.57 \% 19.62 \%$ and $36.58 \%$ respectively.
\end{abstract}

Keywords: Process Design, Heat \& Mass Integration, Biodiesel, Pinch Technology, Heat Exchanger Network.

\section{INTRODUCTION}

Fossil fuels as well as their derivatives have been the greatest energy source over the recent two centuries. Their imminent depletion as well as environmental consequence of their overuse has motivated researchers around the world to look for renewable, less pollutant, cost-effective and reliable source of energy. Biological fuel has received an attention among other renewable energy sources e.g. energy from sun and wind energy, taking into account both greenhouse issue and reliability.

According to International Energy Agency (IEA), in 2011, the global bioenergy use were $1.3 \mathrm{MBOE} / \mathrm{D}$ (million barrels of oil equivalent per day), which will reach to $2.1 \mathrm{MBOE} / \mathrm{D}$ and $4.1 \mathrm{MBOE} / \mathrm{D}$ by 2020 and 2035 respectively; Furthermore in the year 2035, bioenergy fuel will account for almost $8 \%$ of all transportation fuel consumed in the world ${ }^{1}$; indicating global rise in implementing their bio-energy plans over the coming decades.

At least three critical goals can be attained through governmental investment on bioenergy, including: (a) lessening the mounting concerns towards greenhouse gasses, (b) less relying on conventional depleting fossil energy and (c)improving the agriculture sector in rural areas to produce the feed for bio-energy industry. It is to be noted that European countries (and Germany at the top of the list)are the pioneers of bioenergy industry today ${ }^{2}$. Significant deal of research is being carried out throughout the world to apply different sources for bioenergy production as photocurrent generation, biodiesel and bioethanol and bio-hydrogen production and etc ${ }^{3-4}$.

Comparison between biodiesel and conventional diesel indicates that it has not only decreases the main greenhouse gas $\left(\mathrm{CO}_{2}\right)$, by $78 \%$ over a life-cycle ${ }^{5}$, but also can contribute to reduction of $\mathrm{CO}$ through combustion ${ }^{6}$. It can be simply used directly in current diesel engines directly and can be blended (in any proportion) with diesel to improve fuel properties ${ }^{2}$.

The final cost of biodiesel is 1.5-3 times higher than that of the conventional diesel ${ }^{7}$, Nevertheless, it constitutes the main obstacle for its production in industrial scale. Some of drawbacks are mainly high energy consumption, low reactor efficiency, and material/energy loss at various extraction/separation processes ${ }^{8}$.

With the aim of minimization of energy/material consumption and reduction of facility usage, the effect of reactor performance on processing parameters was investigated in this paper. Therefore, in primary optimizations, the materials and streams which were used to lose in the process, were collected and recycled back to the process input/feed; further, to prevent energy loss, pinch method - as one of efficient methods in integration approach - were employed. In this method the extra energy available in the process were partially used to reduce the utility energy uptake. As such, using identical material load and facilities (with different reactor efficiency), two different processes were sketched where trans-esterification reaction under 60 and $1 \mathrm{~atm}$. carried out with overall yield of $97.7 \%$ and $70 \%$ at each.

\section{BIODIESEL}

Biodiesel is a combination of fatty acid esters which can be used as fuel in diesel engines. The ester acid compounds of the biodiesel increase the oxygen content in fuel, leading to higher combustion yield and reduction of air pollution ${ }^{2}$. It can be produced from animal fats, waste oil and plant oils extracted from Soya, Sunflower, Palm and Canola9.

Among various candidates mentioned above, oil from oleaginous crops was found to be reliable, source taking into account the quantity, consistency and continuity of the flow which should be fed into a biodiesel production plant ${ }^{10}$.

Apart from the reliability of the source in question, Fatty Acids (FA) from oleaginous crops, though, cannot be used directly in engines due to its low volatility and high viscosity since it may lead to piston knocking, sedimentation, cocking and other technical troubles ${ }^{11-12}$. To tackle this, researchers have proposed numerous 
solutions e.g. trans-esterification which increases the volatility and decreases viscosity index maintaining the heating value of $\mathrm{FA}^{\mathbf{1 3 - 1 4}}$.

Trans-esterification (Eq. 1) is the reaction of Alcohol with Tri-Glyceride (TG) producing Glycerin ${ }^{\mathbf{1 5}}$. Together with TG, Free Fatty Acid (FFA) can be found in animal and plant oils. If the FFA content would be higher than $1 \%$, it should be removed or converted to biodiesel (Eq. 2) $)^{16-17}$.

Application of catalyst is of key importance in Eq. 1 and 2 due to the nature of the trans-esterification reactions and low solubility of alcohols in FA, and more importantly, low reaction rate, using catalysis has been proposed $^{10}$ e.g. acid, alkali and enzyme catalysts. For trans-esterification of FA obtained from oleaginous crops, homogeneous alkali catalysts are being conventionally used in batch and continuous processes ${ }^{18-19}$, Alkali catalysts are preferred for biodiesel production because it is faster than acid catalyzed trans-esterification reaction ${ }^{\mathbf{2 0}}$. However, enzymatic catalysts have not been proved to be appropriate choice due to insufficient reaction rate $^{\mathbf{2 1}}$.

$\mathrm{TG}+3$ Alcohol $\stackrel{\text { Basic catalyst }}{\longleftrightarrow} 3$ Biodiesel + Glycerol
$\mathrm{FFA}+$ Alcohol $\stackrel{\text { Acid catalyst }}{\longleftarrow}$ Biodiesel + Water
The produced biodiesel should also possess a number of standards which has been clearly elaborated in ASTM 6751-02 along with their testing methods ${ }^{\mathbf{1 0}}$.

\section{Production process}

Production of biodiesel can be carried out through both batch and continuous procedures. In batch process (Fig. 1) the reactor stirrer operates for $20 \mathrm{~min}$ to more than an hour as residence time starting from a vigorous rate down to zero to provide an initial bi-phasic separation of glycerin (higher density) to obtain the final conversion of $85-94 \%$. To further increase the conversion (up to $95 \%$ ), a two-step series reactor was followed at which glycerin was removed between two stages as can be seen in Figure 1.To separate produced esters and glycerin, a settler or centrifuge can be employed; furthermore, the remaining alcohol in both streams can also be removed by Flash evaporation. Finally, to remove the remaining impurities e.g. salts, catalyst and alcohol, the obtained biodiesel and glycerin were rinsed with water andacid ${ }^{\mathbf{1 4 , 2 2}}$.

One of the common modifications in batch production is the application of a series of Completely Stirred Tank Reactors (CSTR) to improve heat transfer and production yield. As can be seen in Figure 2, the CSTR series can also be replaced by a Plug Flow Reactor (PFR) to increase conversion fraction as well as total processing time which drops to 6-10 minutes only ${ }^{23}$. The choice of alternative, however, depends on potential technical

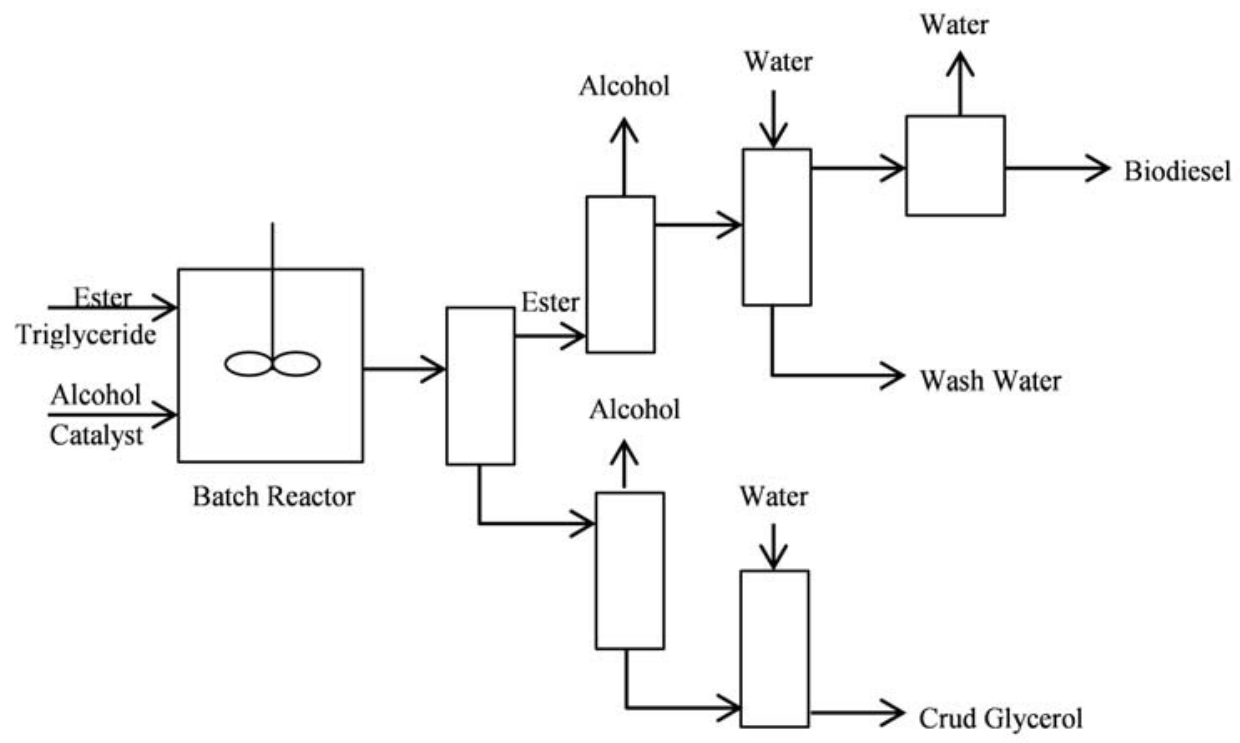

Figure 1. Batch process in biodiesel production

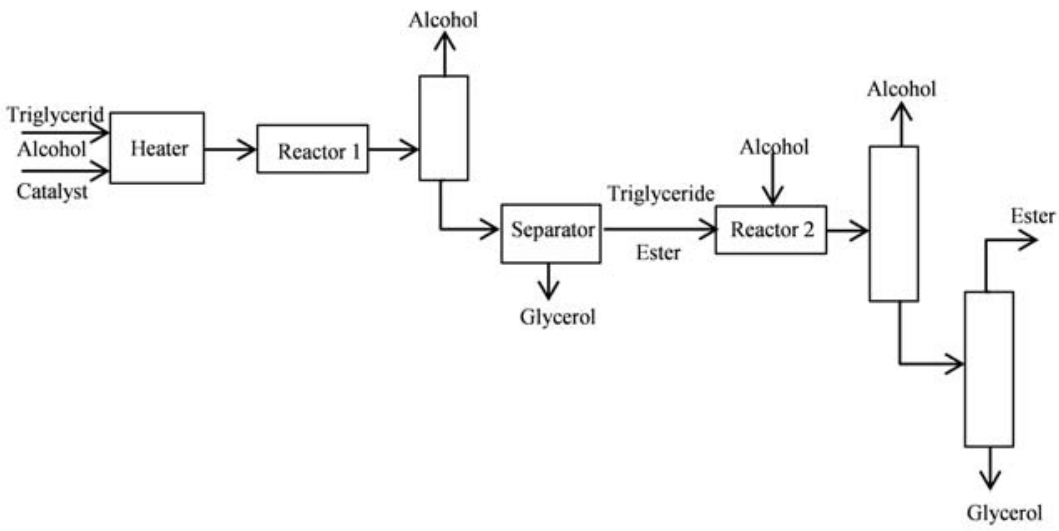

Figure 2. Continuous process in biodiesel production 
troubles, material handling's manner as well as cost/ benefit balance.

\section{Separation of ester and glycerin}

The separation of ester and glycerin carries out after the production of biodiesel in the reactor (chain) based on the density difference among ester (light phase) and glycerin (heavy phase) in centrifuge, decanter or hydro-cyclone. The alcohol content of reactor products (mainly methanol) is the key parameter in mutual miscibility of the two phases ${ }^{24}$.

\section{Alcohol separation}

Alcohol separation contributes the whole process to be more cost-effective and environmentally-friendly since it enters to the reactor in extra proportions and is mainly volatile, flammable and harmful. Moreover, the separation should be carried out prior to ester-glycerol separation, since as has been noted earlier, alcohol content prevents the binary phase separation of ester-glycerol due mainly to practical interaction with water ${ }^{25}$.

\section{Biodiesel treatment}

Separation and purification of the produced biodiesel is of critical importance in overall economy of biodiesel production since the cost associated with this steps mounts to $60-80 \%$ of the total processing cost; furthermore, it may cause a number of serious subsequent technical difficulties when using e.g. filter plugging, higher soot agglomeration, oil adhesion, oil coagulation, engine knocking and failure ${ }^{26}$.

\section{Glycerin treatment}

Glycerin is considered to be the most important by-product of the biodiesel production process with its global consumption quantity mounting to 600 Ktonnes per year being used mainly for cosmetics (almost 28\%) and medical purposes ${ }^{27}$. The final price, however, dropped dramatically to $7.5 \mathrm{US} \$ /$ ton from 110 US\$/ton between 2004 and 2011 due to significant increase in global biodiesel production ${ }^{25}$.

Employing thermo-chemical and biological methods, it can be converted to highly value-added products e.g. propylene glycol, propanoic acid, acrylic acid, propanol, i-propanol and allylalcoho ${ }^{28-29}$. Using Fisher-Trops method in presence of catalyst, the glycerine may be converted to fuel and hydrogen over relatively low temperatures i.e. $225-300^{\circ} \mathrm{C}^{29-30}$.

The separated glycerin includes mainly catalyst, sapon and ester along with negligible quantities of phosphate, sulfur, protein, aldehyde, ketone and dissoluble inorganic compounds. Vacuum distillation as well as physic-chemical techniques can be employed for glycerin separation ${ }^{31}$. The obtained glycerin may also be used as feed in various industries including food, cosmetics, lubricant etc ${ }^{32}$.

\section{PROCESS DESIGN}

HYSYS is a software for steady-state and dynamic process simulation created by Hyprotech as an interactive and flexible process modeling software ${ }^{22,31}$. The simulation was carried out using Aspen HYSYS V7.2 employing Triolein (as TG), Oleic acid (as FFA), and m-Oleate as biodiesel as has already been used in previous communications as model representatives ${ }^{22,31,33}$. To avoid side-stream reactions as well as trans-esterification, the FFA content was taken to be $0.05 \%$ - mass ratio ${ }^{34}$. Feed stream was taken as product of $\mathrm{NaOH}$-catalyzed bi-reactor system operating at $60^{\circ} \mathrm{C}$ and $1 \mathrm{~atm}^{35-37}$ with the overall conversion of $97.7 \%$, using two series reactors has already been investigated in previous researches ${ }^{38-39}$.

Taking into account the low cost, accessibility and handling considerations, methanol was employed in this investigation as the model-type alcohol, since it may not cause difference in chemical structure of final obtained biodiesel ${ }^{39-40}$.

In Eq. 1, the TG:Alcohol ratio is 1:3, though it was taken in extra 1:6 for appropriate reactor performance in practice ${ }^{41-42}$. The design was mainly intended to produce $20 \mathrm{~m}^{3} \mathrm{~h}^{-1}$ biodiesel with mass concentration of $99.65 \%$. As exchanger pressure loss is about $50 \mathrm{kpa}$, the increase of pressure in pumps were taken in a level so that the overall pressure would remain almost at $1 \mathrm{~atm}$. all along the process since higher pressure may cause dramatic effects on reactions and costs. NRTL was taken as the governing Equation of State (EOS) for the process, while for decanters; SRK was used ${ }^{31,43-44}$.

As has been showed in Figure 3, feed-streams reacts in Reac. 1 and the downstream lines flows to Sep. 1 (Separator 1) to separate un-reacted oils as well as the extra methanol. The separator operates at $25^{\circ} \mathrm{C}(1 \mathrm{~atm})$ and the separation carries out in a proportion at which the outlet (Reac. 2 feed) possesses of methanol: oil ratio of higher than (or equal to) 6:1.

Reac. 2 products including glycerin, methanol, biodiesel and oil were flown to Sep. 2 (Separator 2) $\left(25^{\circ} \mathrm{C}\right)$ to separate ester (light) and glycerin (heavy). Light phase (ester) was directed to a recycled distillation column (Dist. 1) with $\mathrm{R}=1.5$ and 6 trays to obtain extra-pure methanol $(100 \%)$ from biodiesel. Biodiesel-containing flow then entered to Sep. 3 (Separator 3) to improve purity and remove remaining catalysts via $\mathrm{HCl}-\mathrm{NaOH}$ neutralization reaction. $\mathrm{HCl}$ and catalyst are fed with identical molar flow and reacts with $95 \%$ conversion fraction to give $99.65 \%$ ultra-pure biodiesel (Table 1).

Table 1. Inlet/Outlet material inbiodiesel production process

\begin{tabular}{|c|c|c|c|c|c|c|c|c|c|c|c|c|}
\hline \multirow[b]{2}{*}{ Stream } & \multirow[b]{2}{*}{$\begin{array}{c}\mathrm{T} \\
{\left[{ }^{\circ} \mathrm{C}\right]}\end{array}$} & \multirow[b]{2}{*}{$\begin{array}{c}\dot{m} \\
{\left[\mathrm{~kg} \mathrm{~h}^{-1}\right]}\end{array}$} & \multirow[b]{2}{*}{$\begin{array}{c}\mathrm{P} \\
{[\mathrm{kPa}]}\end{array}$} & \multicolumn{9}{|c|}{ Mass fraction } \\
\hline & & & & Triolein & Methanol & M-oleate & Glycerol & $\mathrm{H}_{2} \mathrm{O}$ & $\begin{array}{l}\text { Oleic } \\
\text { Acid }\end{array}$ & $\mathrm{HCl}$ & $\mathrm{NaCl}$ & $\mathrm{NaOH}$ \\
\hline $\mathrm{NaOH}$ & 25.0 & 174.8 & 101.3 & 0 & 0 & 0 & 0 & 0 & 0 & 0 & 0 & 1 \\
\hline Methanol & 25.0 & 1905 & 101.3 & 0 & 0 & 0 & 0 & 0 & 0 & 0 & 0 & 0 \\
\hline Oil & 25.0 & 17420 & 101.3 & 0.9995 & 0 & 0 & 0 & 0 & 0.0005 & 0 & 0 & 0 \\
\hline $\begin{array}{l}\text { Methanol } \\
\text { rec }\end{array}$ & 64.4 & 1894 & 101.3 & 0 & 1 & 0 & 0 & 0 & 0 & 0 & 0 & 0 \\
\hline Glycerol-2 & 283.4 & 1816 & 110 & 0 & 0.0005 & 0 & 0.9995 & 0 & 0 & 0 & 0 & 0 \\
\hline Biodiesel & 27.6 & 17600 & 101.3 & 0.0005 & 0.0001 & 0.9965 & 0 & 0.0015 & 0.0005 & 0.0005 & 0 & 0.0005 \\
\hline HLD-3 & 27.6 & 291.2 & 101.3 & 0 & 0.0001 & 0 & 0.0037 & 0.1659 & 0 & 0 & 0.8303 & 0 \\
\hline
\end{tabular}




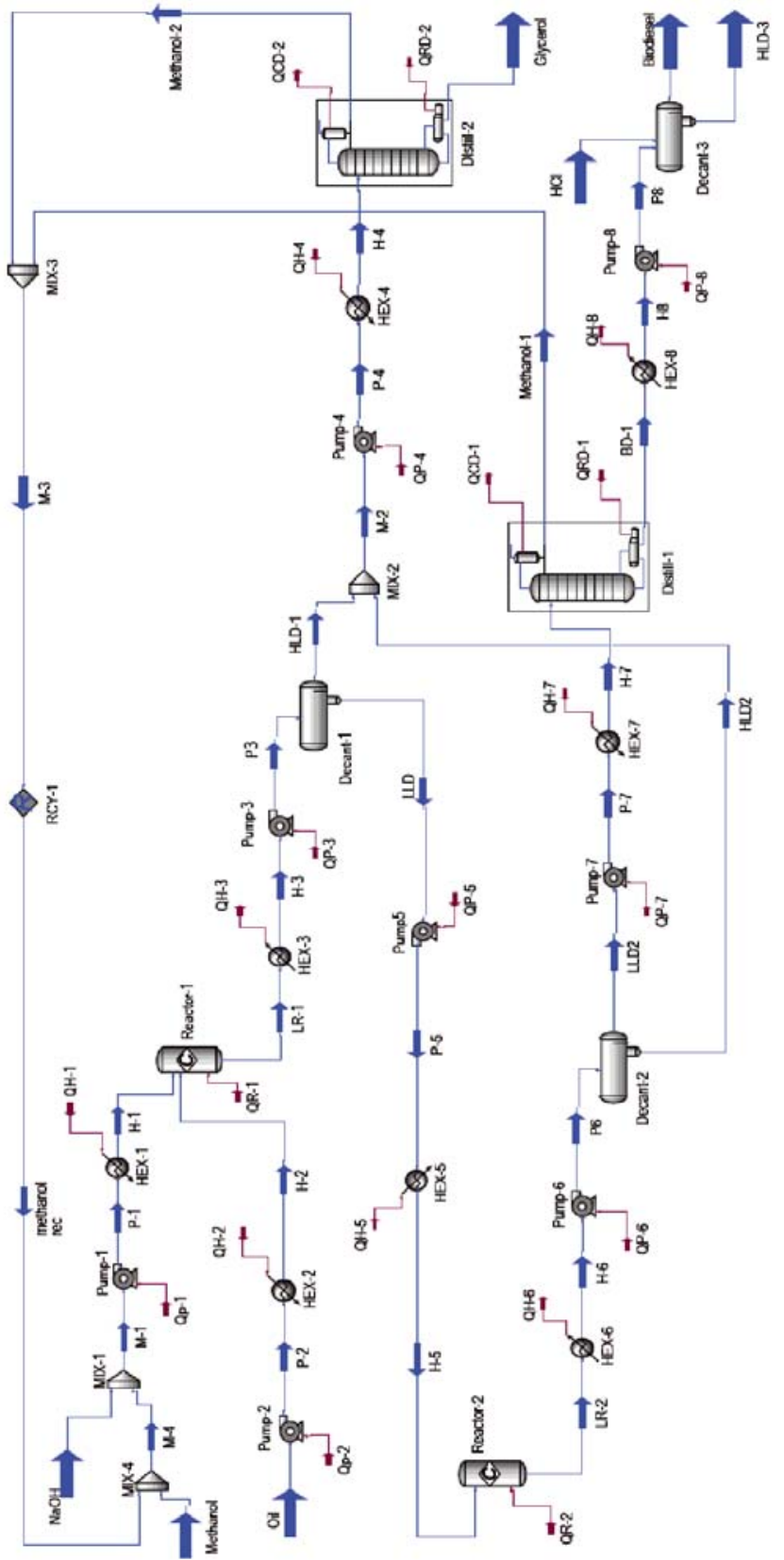

Figure 3. PFD of biodiesel production from vegetable oil

Effluents from Sep. 1 and Sep. 2 having large quantities of methanol and glycerin were directed to second distillation tower (Dist. 2) with 5-tray and $\mathrm{R}=1.5$ to yield pure methanol and glycerin with $100 \%$ and $99.54 \%$ purity respectively, considering their significant difference in boiling points. The obtained methanol recycled back to the beginning of process as a feed; while glycerin was sent out to downstream as by-product.

Finally, the cold energy (sum of cooler and condenser energies) and the hot energy (sum of heater and boiler energies) required for the process were calculated to be $6194 \mathrm{kw}$ and $6884 \mathrm{kw}$ respectively.

\section{HEAT INTEGRATION}

Reducing the processing costs is one of the major challenges for chemical engineers today; which mainly deals with utility costs. Energy consumption can be balanced partially using heat exchangers where energy exchanges between the cold and hot streams. Optimization as well as integration methods based generally on thermodynamic and mathematic approaches. Mathematic methods solve modeling problems e.g. Mixed Integer Non-Linear Programming (MINLP) and Mixed Integer Linear Programming (MILP) equations through classical or stochastic methods ${ }^{44}$.

Thermodynamic methods e.g. Pinch Technology based on thermo-kinetic principals and exergy loss reduction ${ }^{45}$. Pinch technology was first introduced by Linhoffet al. in 1978 to the optimization of heat exchanger networks and lodged pinch point as the critical point of energy consumption ${ }^{46}$.

The method was used here to design exchanger network to reduce energy consumption and loss. Energy consumption reduction, number of used exchangers, required effective area etc., can be assigned as the scope of pinch approach as the first step in pinch design. Energy consumption was taken as the basis of optimization in this study; thereafter, source and demand streams (which can be defined as emission and receiving of energy respectively) were determined. Table 2 demonstrates the thermal characteristics of all streams including source and demand, regardless of the outlet streams like glycerol line. HR-1, HR-2, HD-1 and HD-2 represent cooling water leaving reactors and condensers respectively which flew subsequently to utility to drop water temperature to $25 . \mathrm{C}_{\mathrm{p}}$ is also indicating heat capacity of each line which can be calculated using Eq. 3:

$\mathrm{C}_{\mathrm{p}}=\left(\mathrm{Cp}_{\text {in }}+\mathrm{Cp}_{\text {out }}\right) \cdot \mathrm{m} \cdot / 2$

Where $\mathrm{m} \cdot$ is the flux and $\mathrm{Cp}_{\text {in }} / \mathrm{Cp}_{\text {out }}$ are the heat capacity of inlet/outlet streams. Minimum approach temperature $\left(\Delta \mathrm{T}_{\min }\right)$ was also taken as 10 in the following calculations.

Table 2. Source and demand streams and their heat characteristics

\begin{tabular}{|l|c|c|c|c|}
\hline \multicolumn{1}{|c|}{ Stream } & $\begin{array}{c}\text { Supply temperature } \\
{\left[{ }^{\circ} \mathrm{C}\right]}\end{array}$ & $\begin{array}{c}\text { Target temperature } \\
{\left[{ }^{\circ} \mathrm{C}\right]}\end{array}$ & $\begin{array}{c}\mathrm{CP} \\
{\left[\mathrm{kW} /{ }^{\circ} \mathrm{C}\right]}\end{array}$ & $\begin{array}{c}\Delta \mathrm{H} \\
{[\mathrm{kW}]}\end{array}$ \\
\hline \multicolumn{5}{|c|}{ Cold stream } \\
\hline HEX-1 & 43.9 & 60.0 & 4.1 & 65.6 \\
\hline HEX-2 & 25.0 & 60.0 & 0.64 & 21.8 \\
\hline HEX-4 & 25.0 & 60.0 & 2.2 & 373 \\
\hline HEX-5 & 25.0 & 60.0 & 10.7 & 380 \\
\hline HEX-7 & 25.0 & 60.0 & 10.9 & -0.42 \\
\hline \multicolumn{5}{|c|}{ Hot stream } \\
\hline HEX-3 & 60.0 & 25.0 & 12.8 & -0.36 \\
\hline HEX-6 & 60.0 & 25.0 & 10.9 & -3930.6 \\
\hline HEX-8 & 343.5 & 25.0 & 12.3 & -784.2 \\
\hline HD1-1 & 50.0 & 25.0 & 31.25 & -659.2 \\
\hline HD2-1 & 50.0 & 25.0 & 26.3 & -657.6 \\
\hline HR-1 & 120.4 & 25.0 & 7.1 & -20.1 \\
\hline HR-2 & 100.0 & 25.0 & 0.36 & \\
\hline
\end{tabular}


To calculate interval temperature as the next step, the inlet and outlet temperatures of hot flow must be diffracted from the half of minimum approach temperature of exchangers; and the inlet and outlet cold temperatures should be summed with the half of minimum of approach temperature of exchangers (Eq. 4 and Eq. 5). Interval enthalpy can also be calculated using Eq. 6 .

Hot Interval Temperature $=$ Hot Tem. $-\Delta \mathrm{T}_{\min }$

Cold Interval Temperature $=$ Cold Tem. $+\Delta \mathrm{T}_{\min }$

$\Delta \mathrm{H}_{\text {interrval }}=\Delta \mathrm{T}_{\text {interval }}\left[\mathrm{C}_{\mathrm{PCold}}-\mathrm{C}_{\mathrm{PHot}}\right]$

According to Table 3, the required hot and cold energy for the network were found to be zero and $5988.4 \mathrm{kw}$ respectively; where the number "zero" indicates that the source stream is able of providing all energy required by demand stream, whereas $5988.4 \mathrm{kw}$ shows that a make-up energy with this magnitude should be transferred from utility to process in furtherance of the energy given by source stream to the demand. Moreover, as can be seen, there is no pinch temperature among interval temperatures confirming of no limitation for energy transfer between streams, according to pinch principals. Care should be taken that the exchanger approach tem-

Table 3. Cold and Hot utility calculation of exchanger network

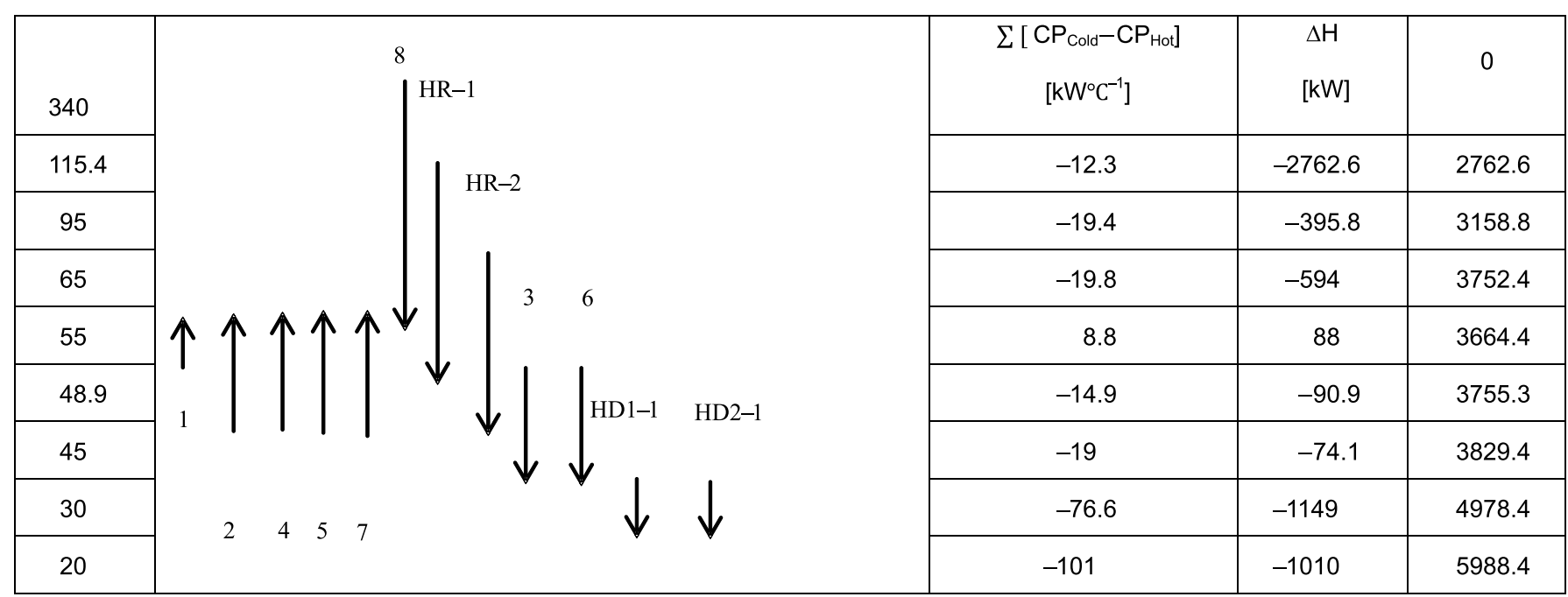

perature should not be less than the minimum selected approach temperature.

According to Table 2, since the considered source streams were able of providing required network energy, the energy from the rebuilders heat source were not taken into account; additionally, utilization of energy from source stream possessing " $300^{\circ} \mathrm{C}$ and $1 \mathrm{MPa}$ " merely to warm other streams to the maximum of $60^{\circ} \mathrm{C}$ is not cost-effective and it should be saved for essential cases e.g. boilers. Taking all Pinch principals and processing issues into consideration, the plant demonstrated in Figure 4 was plotted and re-characterized.

Applying the new system (Fig. 4) in the process, cold and hot energy reduced to $5991.4 \mathrm{kw}$ and $5273.6 \mathrm{kw}$ respectively at which the hot energy is consumed merely for heating the distillation reboilers. From Table 4 and Figure 4, HEX-8 can be used as energy source for the second distillation tower's reboilers which result in $14.68 \%$ reduction of cold energy and $16.67 \%$ reduction in hot energy consumption. Table 5 provides a comparative report on the effect caused by applying the integration method.

To investigate the effect of conversion on process, similar $20 \mathrm{~m}^{3} \mathrm{~h}^{-1}$ production unit was designed using

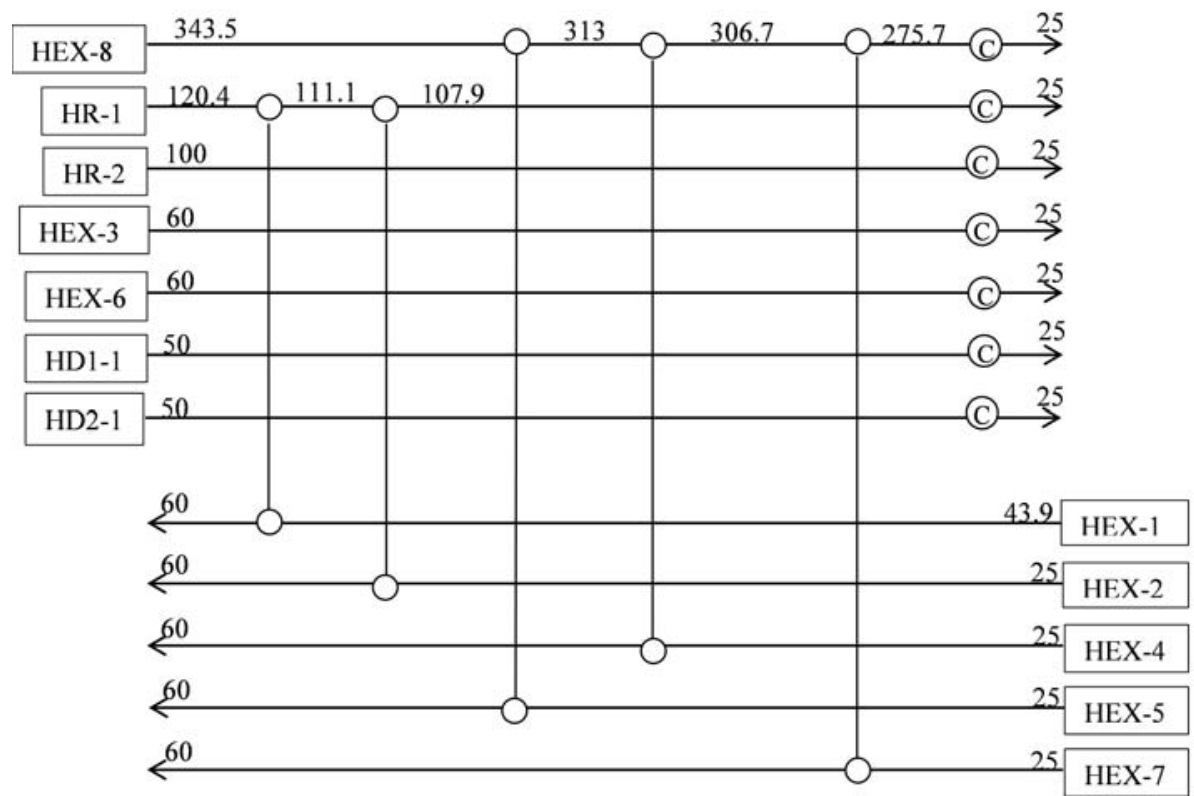

Figure 4. Heat exchanger network in the biodiesel productionprocess 
Table 4. Heat characteristics of distillation tower reboilers

\begin{tabular}{|l|c|c|c|}
\hline Reboiler & $\mathrm{T}_{\text {in }}\left[{ }^{\circ} \mathrm{C}\right]$ & $\left.\mathrm{T}_{\text {out }}{ }^{\circ} \mathrm{C}\right]$ & $\Delta \mathrm{H}[\mathrm{kW}]$ \\
\hline First column & 162.1 & 343.5 & 4394 \\
\hline Second column & 81.0 & 231.7 & 879.7 \\
\hline
\end{tabular}

Table 5. Obtained results from first and second results

\begin{tabular}{|l|c|c|c|c|}
\hline & \multicolumn{2}{|c|}{ First design } & \multicolumn{2}{c|}{ Second design } \\
\hline process parameters & before integration & after integration & before integration & after integration \\
\hline Inlet oil $\left[\mathrm{kg} \mathrm{h}^{-1}\right]$ & 17420 & 17420 & 19170 & 17440 \\
\hline Inlet methanol $\left[\mathrm{kg} \mathrm{h}^{-1}\right]$ & 3788 & 1901 & 4855 & 1914 \\
\hline Outlet Glycerol $\left[\mathrm{kg} \mathrm{h}^{-1}\right]$ & 1818 & 1818 & 1834 & 1834 \\
\hline No. Distillation column & 2 & 2 & 3 & 3 \\
\hline No. of heat transfer equipment & 8 & 10 & 9 & 14 \\
\hline No. of pump & 8 & 8 & 9 & 9 \\
\hline Total pump power $[\mathrm{kW}]$ & 2.6 & 4.9 & 2.7 & 5.9 \\
\hline Cold energy $[\mathrm{kW}]$ & 6194 & 5112.2 & 18860 & 15160 \\
\hline Hot energy $[\mathrm{kW}]$ & 6884 & 4394 & 17330 & 10990 \\
\hline
\end{tabular}

same facilities and materials. In the new design, however, two series reactors $(X=70 \%)$ were employed. In these conditions, the output biodiesel concentration (mass fraction) in Sep. 3 is $90.8 \%$ which was sent to another distillation tower with 5 trays and recycle flow ratio 1.5 directly to further increase biodiesel concentration.

The upstream line on top of this tower includes biodiesel with appropriate purity, whereas downstream contains a great deal of triolein because more than $30 \%$ of the feed remains un-reacted. Therefore purification reactors for triolein treatment were used as has been used in the earlier design. The downstream line for increasing in purity and recycle to the feed stream sent to separator at $25^{\circ} \mathrm{C}$; this operation resulted in triolein with $99.51 \%$ mass concentration. Hence, in this new process, a distillation tower, a heat exchanger, a pump and another separator were added after Sep. 3 .

In this design, to reduce energy consumption, exchanger networks have been designed applying pinch method with the minimum approach temperature of $10^{\circ} \mathrm{C}$; the results were shown in Table 5.

\section{CONCLUSION}

Application of recycle stream and mass integration has reduced methanol consumption up to $49.81 \%$ and $60.57 \%$ in first and second design respectively. In the second design, since there is still a significant quantity of un-reacted oil, it can be recycled back into feed and reduce the oil consumption up to $9 \%$. Cold and Hot energies were also reduced $17.46 \%$ and $36.17 \%$ respectively in first and $19.6 \%$ and $36.6 \%$ in second design respectively. The number/capacity of used facilities increased in some cases as a result of application of integration method; this item can be also optimized depending on relative price of feed, used facilities or other technical considerations.

From the results, it can be deduced that the increase of reactor conversion from $70 \%$ to $97.7 \%$, caused a significant reduction in consumed oil $(9.1 \%)$, methanol (22\%), cold energy (67\%) and hot energy (60.3\%); in addition to reduction of a number of used facilities e.g. distillation tower and exchangers, were reduced.

\section{LITERATURE CITED}

1. Gadonneix, P., de Castro, F.B., de Medeiros, N.F., Drouin, R., Jain, C., Kim, Y.D., Ferioli, J., Nadeau, M.J., Sambo, A.
\& Teyssen, J. (2010). Biofuels: Policies, Standards and Technologies.

2. Gutiérrez, L.F., Sánchez, Ó.J. \& Cardona, C.A. (2009). Process integration possibilities for biodiesel production from palm oil using ethanol obtained from lignocellulosic residues of oil palm industry. Biores. Technol. 100(3), 1227-1237. DOI: 10.1016/j.biortech.2008.09.001.

3. Mohammadpour, R., Janfaza, S. \& Abbaspour-Aghdam, F. (2014). Light harvesting and photocurrent generation by nanostructured photoelectrodes sensitized with a photosynthetic pigment: A new application for microalgae. Biores. Technol. 163, 1-5. DOI: 10.1016/j.biortech.2014.04.003.

4. Valizadeh Derakhshan, M., Nasernejad, B., Abbaspour-Aghdam, F. \& Hamidi, M. (2015). Oil extraction from algae: A comparative approach. Biotechnol. Appl. Bioc. 62(3), 375-382. DOI: 10.1002/bab.1270.

5. Tyson, K.S. (2009). Biodiesel Handling and Use Guidelines (3rd ed.). Borough, USA: DIANE Publishing Company.

6. Schumacher, L.G. 1995. Biodiesel Emissions Data From Series 60 DDC Engines. in: Bus Operations and Technology Conference. Reno, Nevada.

7. Demirbas, A. (2009). Progress and recent trends in biodiesel fuels. Energy Conv. Manage. 50(1), 14-34. DOI: 10.1016/j. enconman.2008.09.001.

8. Agarwal, M., Singh, K. \& Chaurasia, S. (2012). Simulation and sensitivity analysis for biodiesel production in a reactive distillation column. Pol. J. Chem. Technol. 14(3), 59-65. DOI: 10.2478/v10026-012-0085-2.

9. Hoekman, S.K., Broch, A., Robbins, C., Ceniceros, E. \& Natarajan, M. (2012). Review of biodiesel composition, properties, and specifications. Ren Sust. Energy Rev. 16(1), 143-169. DOI: 10.1016/j.rser.2011.07.143.

10. Rutz, D. \& Janssen, R. 2007. Biofuel technology handbook, Munich, Germany, WIP Renewable Energies.

11. Perkins, L.A., Peterson, C.L. \& Auld, D.L. 1991. Durability Testing of Transesterified Winter Rape Oil (Brassica Napus L.) as Fuel in Small Bore, Multi-cylinder, DI, CI Engines. Society of Automotive Engineers.

12. Pestes, M. \& Stanislao, J. (1984). Piston Ring Deposits When Using Vegetable Oil as a Fuel. J. Test Eval. 12(2), 24-32. DOI: 10.1520/JTE10699J.

13. Canakci, M. \& Van Gerpen, J. (1999). Biodiesel production via acid catalysis. T ASAE 42(5), 1203-1210. DOI: 10.13031/2013.13285.

14. Gerpen, J.V. (2005). Biodiesel processing and production. Fuel Process Technol. 86(10), 1097-1107. DOI: 10.1016/j. fuproc.2004.11.005.

15. Kusy, P.F. (1982). Transesterification of vegetable oils for fuels. Am. Soc. Agric. Enginee. (4-82), 127-137.

16. Balat, M. \& Balat, H. (2010). Progress in biodiesel processing. Appl. Energ. 87(6), 1815-1835. DOI:10.1016/j. apenergy.2010.01.012. 
17. Cho, H.J., Kim, S.H., Hong, S.W. \& Yeo, Y.K. (2012). A single step non-catalytic esterification of palm fatty acid distillate (PFAD) for biodiesel production. Fuel 93(0), 373-380. DOI: $10.1016 /$ j.fuel.2011.08.063.

18. Kiss, A.A. \& Bildea, C.S. (2012). A review of biodiesel production by integrated reactive separation technologies. J. Chem. Technol. Biot. 87(7), 861-879. DOI: 10.1002/jctb.3785.

19. Helwani, Z., Othman, M.R., Aziz, N., Kim, J. \& Fernando, W.J.N. (2009). Solid heterogeneous catalysts for transesterification of triglycerides with methanol: A review. Appl. Catal A-Gen. 363(1-2), 1-10. DOI: 10.1016/j.apcata.2009.05.021.

20. Dawodu, F.A., Ayodele, O.O., Xin, J. \& Zhang, S. (2014). Application of solid acid catalyst derived from low value biomass for a cheaper biodiesel production. J. Chem. Technol. Biot. 89(12), 1898-1909. DOI: 10.1002/jctb.4274.

21. Ma, F. \& Hanna, M.A. (1999). Biodiesel production: a review. Biores. Technol. 70(1), 1-15. DOI: 10.1016/S09608524(99)00025-5.

22. Gomez-Castro, F.I., Rico-Ramirez, V., Segovia-Hernandez, J.G., Hernandez-Castro, S. \& El-Halwagi, M.M. (2013). Simulation study on biodiesel production by reactive distillation with methanol at high pressure and temperature: Impact on costs and pollutant emissions. Comput. Chem. Eng. 52(0), 204-215. DOI: 10.1016/j.compchemeng.2013.01.007.

23. Portha, J.F., Allain, F., Coupard, V., Dandeu, A., Girot, E., Schaer, E. \& Falk, L. (2012). Simulation and kinetic study of transesterification of triolein to biodiesel using modular reactors. Chem. Eng. J. 207-208(0), 285-298. DOI: 10.1016/j. cej.2012.06.106.

24. Bondioli, P. (2005). Overview from oil seeds to industrial products: Present and future oleochemistry. J. Synth. Lubric. 21(4), 331-343. DOI: 10.1002/jsl.3000210406.

25. Yazdani, S.S. \& Gonzalez, R. (2007). Anaerobic fermentation of glycerol: a path to economic viability for the biofuels industry. Curr. Opin Biotech. 18(3), 213-219. DOI: 10.1016/j. copbio.2007.05.002.

26. Johnson, D.T. \& Taconi, K.A. (2007). The glycerin glut: Options for the value-added conversion of crude glycerol resulting from biodiesel production. Environ Prog. 26(4), 338-348. DOI: $10.1002 /$ ep.10225.

27. Veillette, M., Chamoumi, M., Nikiema, J., Faucheux, N. \& Heitz, M. (2012). Production of Biodiesel from Microalgae. In: Z. Nawaz, S. Naveed (Eds.), Adv. Chem. Enginee. (245-265). Karachi, Pakistan: InTech.

28. Soares, R.R., Simonetti, D.A. \& Dumesic, J.A. (2006). Glycerol as a Source for Fuels and Chemicals by Low-Temperature Catalytic Processing. Angew Chem. Int Edit. 45(24), 3982-3985. DOI: 10.1002/anie.200600212.

29. Vaidya, P.D. \& Rodrigues, A.E. (2009). Glycerol Reforming for Hydrogen Production: A Review. Chem. Eng. Technol. 32(10), 1463-1469. DOI: 10.1002/ceat.200900120.

30. Levy, M. (2013). Simulation of Biodiesel Production Using Reactive Distillation (RD). Bachelor of Science degree Dissertation, Department of Chemical Engineering, University of Florida. Gainesville, Florida, United States.

31. García, M., Gonzalo, A., Sánchez, J.L., Arauzo, J. \& Peña, J.Á. (2010). Prediction of normalized biodiesel properties by simulation of multiple feedstock blends. Biores. Technol. 101(12), 4431-4439. DOI: 10.1016/j.biortech.2010.01.111.

32. Galadima, A. \& Muraza, O. (2014). Biodiesel production from algae by using heterogeneous catalysts: A critical review. Energy 78(0), 72-83. DOI: 10.1016/j.energy.2014.06.018.

33. Freedman, B., Pryde, E.H. \& Mounts, T.L. (1984). Variables affecting the yields of fatty esters from transesterified vegetable oils. J. Am. Oil Chem. Soc. 61(10), 1638-1643. DOI: 10.1007/bf02541649.

34. West, A.H., Posarac, D. \& Ellis, N. (2008). Assessment of four biodiesel production processes using HYSYS.Plant. Biores.Technol. 99(14), 6587-6601. DOI: 10.1016/j.biortech.2007.11.046.
35. Pokoo-Aikins, G., Nadim, A., El-Halwagi, M. \& Mahalec, V. (2010). Design and analysis of biodiesel production from algae grown through carbon sequestration. Clean Technol. Envir. 12(3), 239-254. DOI: 10.1007/s10098-009-0215-6.

36. Samuel, O., Waheed, M., Bolaji, B. \& Dairo, O. (2014). Synthesis of Biodiesel from Nigerian Waste Restaurant Cooking Oil: Effect of $\mathrm{KOH}$ Concentration on Yield. Global J. Sci. Enginee. Technol. (15), 1-8 .

37. Wong, Y. \& Devi, S. (2014). Biodiesel Production from used Cooking Oil. Orient. J. Chem. 30(2), 521-528. DOI: 10.13005/ojc/300216.

38. Slinn, M. \& Kendall, K. (2009). Developing the reaction kinetics for a biodiesel reactor. Biores. Technol. 100(7), 2324-2327. DOI: 10.1016/j.biortech.2008.08.044.

39. Ye, J., Tu, S. \& Sha, Y. (2010). Investigation to biodiesel production by the two-step homogeneous base-catalyzed transesterification. Biores. Technol. 101(19), 7368-7374. DOI: 10.1016/j.biortech.2010.03.148.

40. Chisti, Y. (2007). Biodiesel from microalgae. Biotech. Adv. 25(3), 294-306. DOI :10.1016/j.biotechadv.2007.02.001.

41. Berrios, M. \& Skelton, R.L. (2008). Comparison of purification methods for biodiesel. Chem. Eng. J. 144(3), 459-465. DOI: 10.1016/j.cej.2008.07.019.

42. Romero, R., Natividad, R. \& Martínez, S.L. (2011). Biodiesel production by using heterogeneous catalysts. In: M. Manzanera (Eds.), Alternative Fuel, 3-20. Rijeka, Croatia: InTech.

43. Renner, G. \& Ekárt, A. (2003). Genetic algorithms in computer aided design. Comp. Aid. Design. 35(8), 709-726. DOI: 10.1016/S0010-4485(03)00003-4.

44. Sánchez, E., Ojeda, K., El-Halwagi, M. \& Kafarov, V. (2011). Biodiesel from microalgae oil production in two sequential esterification/transesterification reactors: Pinch analysis of heat integration. Chem. Eng. J. 176-177(0), 211-216. DOI: 10.1016/j.cej.2011.07.001.

45. Zhelev, T.K. \& Ridolfi, R. (2006). Energy recovery and environmental concerns addressed through emergy-pinch analysis. Energy 31(13), 2486-2498. DOI: 10.1016/j.energy.2005.10.021.

46. Kemp, I.C. (2011). Pinch Analysis and Process Integration: A User Guide on Process Integration for the Efficient Use of Energy (2nd ed.). Oxford, UK: Butterworth-Heinemann. 